\title{
BLOODSHED AND BREAKING WAVE: THE FIRST OUTBREAK OF SOMALI PIRACY
}

\author{
Andreas Bruvik Westberg ${ }^{1}$ \\ Institute of Strategy, Royal Danish Defence College
}

\begin{abstract}
Ten years ago, Somalia suffered its first outbreak of piracy. In early 2005, pirates began appearing hundreds of nautical miles out at sea, attacking and hijacking vessels off the shores of central Somalia. However, the circumstances of this outbreak remain poorly understood. Why did pirate groups originate from an area with a negligible history of maritime predation? The present study explored the environment within which Somalia's first outbreak of piracy occurred, and offers a critical re-think of its origins. Drawing on the author's own extensive fieldwork as well as contemporary reports, the study explored how pirate ventures were launched after the Indian Ocean tsunami on 26 December 2004 had obliterated the coastal economy. The tsunami coincided with the eruption of a deadly and highly destabilising conflict, unprecedented for a coastal area that had remained relatively peaceful since the state collapse in 1991. The tsunami and the establishment of the South Mudug piracy model in Harardhere and Hobyo in 2005 laid the foundation for a decade of ransom piracy.
\end{abstract}

\section{Introduction}

In 2005, the number of pirate attacks off the Horn of Africa increased dramatically. Pirates began appearing hundreds of nautical miles off the eastern coast of Somalia, preying on vessels in the Indian Ocean. This new attack pattern represented a significant change from previous years, when pirate attacks had been sporadic and opportunistic. In earlier years, attacks were limited to the coastal areas of the Gulf of Aden and the southern coast, and the anchorage of hijacked vessels was never focused off one village. Indeed, in the period between 1991 and 2004, piracy appeared distinctly irregular, suggesting the absence of any groups purely

Scientia Militaria, South African Journal of Military Studies, Vol 43, No. 2, 2015, pp. 1-38. doi : $10.5787 / 43-2-1122$ dedicated to piracy. However, in 2005, newly formed pirate groups launched repeated attacks against vessels passing the Horn of Africa. Captured vessels were commandeered to the South Mudug coastline, where pirate groups 
negotiated a ransom payment for vessel and crew. But why did 'blue water' piracy, defined in the present study as distances of more than two hundred nautical miles from the coast, suddenly occur off an area of Somalia with a negligible history of maritime predation?

The outbreak of piracy in 2005 is a hitherto poorly understood phenomenon. Previous studies addressing the outbreak have linked it to the stability of central Somalia in 2005 . $^{2}$ However, the assumption of a stable and peaceful region has never been properly tested. Nor have previous studies soberly considered the local economic and security situation in central Somalia prior to and during the outbreak. This article therefore offers a critical re-think of the outbreak of piracy. Pirate groups formed in a region plagued by a profound breakdown of security and significant disruptions to economic activity. Between 2004 and 2006, Somalia's central South Mudug region was experiencing a destabilising and deadly conflict, unprecedented in scope for a coastal area that had remained relatively peaceful since the state collapse in 1991. The conflict coincided with the Indian Ocean tsunami on 26 December 2004, which wiped out the fishing sector in the South Mudug coastal villages of Hobyo and Harardhere.

The context of the 2005 outbreak of piracy is explored through new fieldwork material from central and northeast Somalia. Data collected through the author's interviews and observations with and of local government officials, fishermen and inhabitants of Harardhere, Hobyo, Garacad, Eyl, Bandarbeyla and Aris offer a rethink of the first outbreak of piracy in Somalia. The article offers a review of piracy statistics off the Horn of Africa for the period 1991 to 2007, based on the author's dataset on registered pirate incidents reported by the International Maritime Organization (IMO) and the National Geospatial-Intelligence Agency (NGIA). New data are provided from contemporary reports, shedding light on the socioeconomic and security environment along Somalia's central and northeast coastline. Moreover, the study presents a comprehensive assessment of the effect and aftermath of the Indian Ocean tsunami on 26 December 2004.

The first section of the article reports on the statistics for Somali piracy between 1991 and 2004, and shows how pirate groups never appeared to have been organised at any point during this period. The second section reports on the timing of the 2005 escalation off Somalia's central South Mudug region. The third section reports on an exploration of the hitherto obscure South Mudug conflict, revealing how it destabilised and marginalised the coastal villages of Hobyo and Harardhere. The fourth section reports on the effect of the Indian Ocean tsunami on 26 December 2004 and on an investigation of its role in breaking down the coastal economy of northeast and central Somalia. The fifth section of the analysis reports 
on an examination of the escalation of piracy in 2005 and the establishment of the South Mudug piracy model. The article reflects an explicit link between former fishing companies and new pirate ventures. The sixth section of the article offers an explanation of why the security and economic environment from 2005 onwards was conducive to such a development in South Mudug. It also provides an explanation of the break in and subsequent re-emergence of pirate attacks between 2006 and 2007. Finally, the article reports on an exploration of the continuation and escalation of piracy after 2007, notably along Puntland's coast. The article concludes with recommendations for future research within the field.

\section{Irregular piracy, 1991-2004}

This section explores the extent of piracy activities along Somalia's coastline prior to 2005. The unequivocal collapse of the state in 1991 ushered Somalia deeper into civil war. ${ }^{3}$ Yet, the absence of a state did not equal an age of piracy. Indeed, there were as many hijackings between 2005 and 2007 as there were in the entire period between 1991 and 2004. ${ }^{4}$ Understanding why piracy became a qualitatively different beast in 2005 is contingent on recognising the irregularity of piracy in the preceding fourteen years. Pirate attacks were infrequent and opportunistic prior to 2005, and quite distinct from the organised and highly repetitive attack patterns observed from 2005 onwards. $^{\text {a }}$

Indeed the first hijacking, of the vessel MV Naviluck, occurred as early as 12 January 1991. However, the second did not take place until 9 September 1994, with the capture of the MV Bonsella. Between 1994 and 2004, there were 32 hijackings, and most occurred along the northeast coastline. ${ }^{5}$ Yet, despite witnessing the daily traffic of one of the busiest shipping lanes on the planet, coastal northeast villages such as Xabo, Bolimoog and Alula hosted few pirate attacks in the 1990s and early 2000s. When attacks occurred from these areas, they did so not due to the presence of organised pirate groups, but due to opportunistic chance.

Arguably, the defining characteristic of hijacked vessels in the period 1991 to 2004 is that they were moving slowly and hugging the coastline. Most victims were, by the nature of their vessels, especially vulnerable to predation, and were commonly fishing vessels, dhows, yachts or lesser cargo vessels with modest maximum speeds and low freeboards. ${ }^{6}$ In this period, there was never any concentration in time of attacks from one village. Rather, attacks were scattered somewhat randomly across several villages. When vessels were hijacked some were

\footnotetext{
${ }^{\mathrm{a}}$ See Figure 1.
} 
simply looted. Other vessels, like the German-owned yacht Bambola, appear to have been the misfortunate victims of opportunistic human traffickers crossing the Gulf of Aden. Many of the reports of pirate approaches have later been ascribed to human traffickers and smugglers. ${ }^{7}$ Others appeared paramilitary in identity, and in 2001, the NGIA noted how repeated incidents were reported near islands in the southern Red Sea, subject to a dispute between Eritrea and Yemen. ${ }^{8}$ Indeed, the majority of the incidents in the Gulf of Aden that were reported in the late 1990s and early 2000s occurred close to the Yemeni coastline, where Yemeni paramilitaries have repeatedly operated to interdict smugglers. ${ }^{9}$

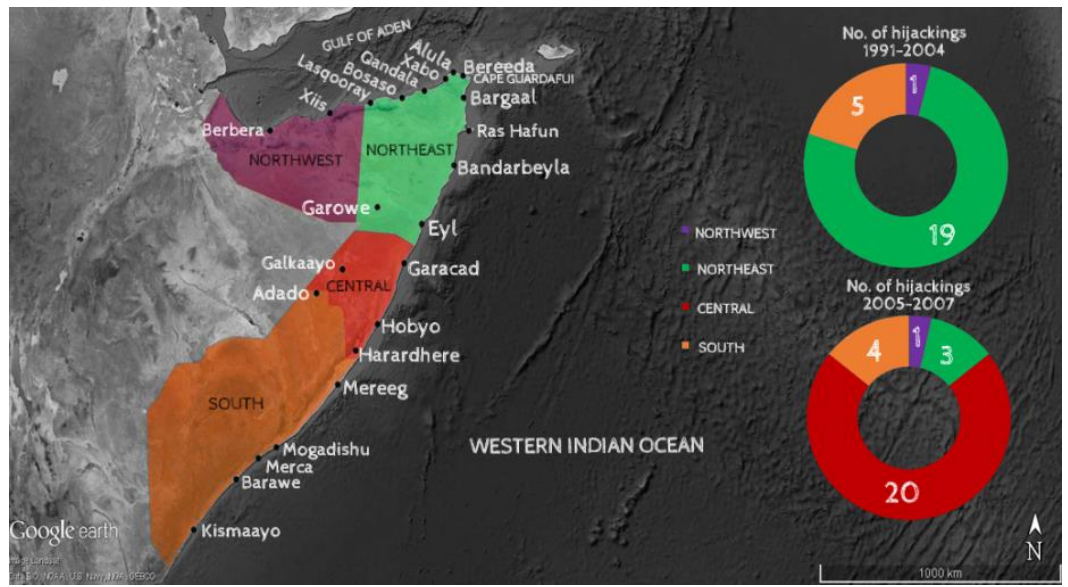

Figure $1^{\text {b}}$ : Number of hijacked vessels in Somalia (by region), 1991-2007 ${ }^{10}$

Eleven of the 34 vessels hijacked by Somali pirates between 1991 and 2004 were fishing trawlers, and represent roughly a third of all hijackings. ${ }^{11}$ Recorded and anecdotal evidence of the level of illegal fishing in the 1990s is fragmentary, but the fishing defence narrative might hold some truth. ${ }^{12}$ Weldemichael ties piracy to general armed resistance by fishermen against a combination of the dumping of toxic and hazardous waste by foreign vessels, and towards illegal and unregulated fishing by Asian and European trawlers. ${ }^{13}$ According to Weldemichael, the dumping of waste materials evoked "strong feelings among Somalis", legitimising a backlash. ${ }^{14}$ Murphy also contends that defensive piracy was committed by aggrieved local fishermen attempting to stave off foreign fishing vessels. ${ }^{15}$ Yet, while fishing

\footnotetext{
${ }^{\mathrm{b}}$ The statistics do not include vessels that were not taken to anchorage in either of the four regions (vessel and crew looted and subsequently left at sea).
} 
vessels figure more prominently than others, this narrative does not sit entirely well with the statistics. ${ }^{16}$

The first two hijackings off Somalia were committed against non-fishing vessels. ${ }^{17}$ In fact, none of the first five incidents that were recorded between 1991 and 1994, including approaches, attempts and hijackings, were made against fishing trawlers. ${ }^{18}$ Moreover, the eleven fishing trawlers that were hijacked were also distributed relatively evenly across time. ${ }^{19}$ Marchal claims that when foreign fishing trawlers began arming themselves, local fishermen were forced to hire militia. ${ }^{20}$ Murphy and Weldemichael contend that fishermen purportedly received help from former coastguards already in the early 1990s. ${ }^{21}$ Together they captured trawlers that were illegally fishing within a few nautical miles from the coast. ${ }^{22}$ Such defensive attacks are what Weldemichael describes as a "legitimate local response that went awry". 23

Moreover, there were reports of clan militias engaging in piracy by 'taxation'. ${ }^{24}$ In 1997, the Taiwanese-flagged trawler MV Shen Kno II was captured by the Somali Salvation Democratic Front, the political organisation that represented the Majeerteen clan. The militia managed to extract US\$800 000 for the ship's release. ${ }^{25}$ Such instances have prompted the suggestion that the Majeerteen clan has profited from a taxation regime due to the clan's close proximity to international shipping lanes. This explanation ties into historical regimes of protection money that have existed in Somalia. ${ }^{26}$ However, this appears too simplistic, and it does not provide a satisfying account for the timing of organised piracy.

It also fails to explain why proximate sub-clans in the northeast, like the Ali Suleiman, the Siwaqroon and the Osman Mahamoud, have been numerically underrepresented in the piracy business. There is a discrepancy with this narrative in that piracy has been infrequent in villages like Xabo, Bereeda, Gumbah and Hurdiyo. This area, spanning the arc of Cape Guardafui, contains the richest marine habitat off the Somali coastline. ${ }^{27}$ Here, an upwelling of cold, nutrient-rich currents produces a particularly favourable environment for marine life. ${ }^{28}$ Fishermen's complaints against illegal fishing have been vociferous, but these complaints did not translate into organised piracy in the 1990s nor in the early 2000s.

Another variant of the fishing defence narrative points to the role of coastguard ventures between 1998 and 2004. Coastguard activities and recruitment are argued to have facilitated the professionalisation of maritime predation off Somalia. ${ }^{29}$ The coastguard argument builds, in part, on the illegal fishing narrative and the protection of maritime resources. Murphy explains how Puntland's first president, Abdulahi Yusuf, established the Puntland International Development 
Company (PIDC) in mid-1999. The company was handed exclusive management of Puntland's maritime resources, and in September 1999, they formed an agreement with the security company Hart Nimrod, establishing a maritime security force to enforce the oversight and protection of Puntland's Exclusive Economic Zone (EEZ). ${ }^{30}$

In January 2000, the State of Puntland declared that all further fishing activities by foreign vessels was contingent on their possession of a valid fishing licence. ${ }^{31}$ Equipped with a single trawler converted into a patrol vessel, the Hart Nimrod-led maritime security force was tasked with patrolling an estimated 160000

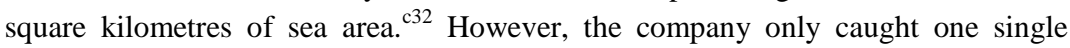
fishing vessel, the Spanish-owned Albaco Cuatro, before its operations ceased in 2001. The basis of dissolving the venture remains unclear, although Murphy argues that it was not lucrative enough for neither the administration nor Hart Nimrod. Yet, in 2002, the Abdulahi Yusuf administration decided to form a new joint venture with the Somali-Canadian-owned company, SomCan. ${ }^{33}$ SomCan boasted, according to Bahadur, a small fleet of six patrol vessels and a force of six hundred marines. ${ }^{34}$ The company appeared to take the sale and enforcement of fishing licences one step further, developing a model akin to a maritime protection racket

Bahadur, Marchal and (in part) Murphy trace the formation of pirate groups to "these failed coast-guarding experiments; with few other opportunities for their skills, many ex-coast-guard recruits turned to piracy". ${ }^{335}$ Additionally, underlines Bahadur, "SomCan actively defended both foreign and domestic 'licensed' fishing vessels from local fishermen". ${ }^{36}$ Anti-illegal fishing grievances were in this way fuelled by the Hart Nimrod and SomCan operations as they were little more than "private militia for the protection of commercial trawlers in possession of 'fishing licences" ${ }^{37}$ A single incident, pertaining to the Thailand-owned fishing trawler Sirichainava 12 , is frequently used as evidence. ${ }^{\mathrm{e} 3839}$ Whether the Sirichainava 12 qualifies in line with conventional Somali piracy hijackings is an interesting question as it was seized by its own protection crew, employees of SomCan, who apparently were "provoked by the non-payment of [their] monthly $\$ 200$ salary". 40 After seizing the vessel the employees demanded a fee of US\$800 000 for its release. ${ }^{41}$

\footnotetext{
${ }^{\mathrm{c}}$ Corresponding to the State of Puntland's claimed Economic Exclusive Zone.

${ }^{\mathrm{d}}$ Although Murphy, to his credit, allows for some uncertainty.

${ }^{\mathrm{e}}$ Seized on 16 March 2005.
} 


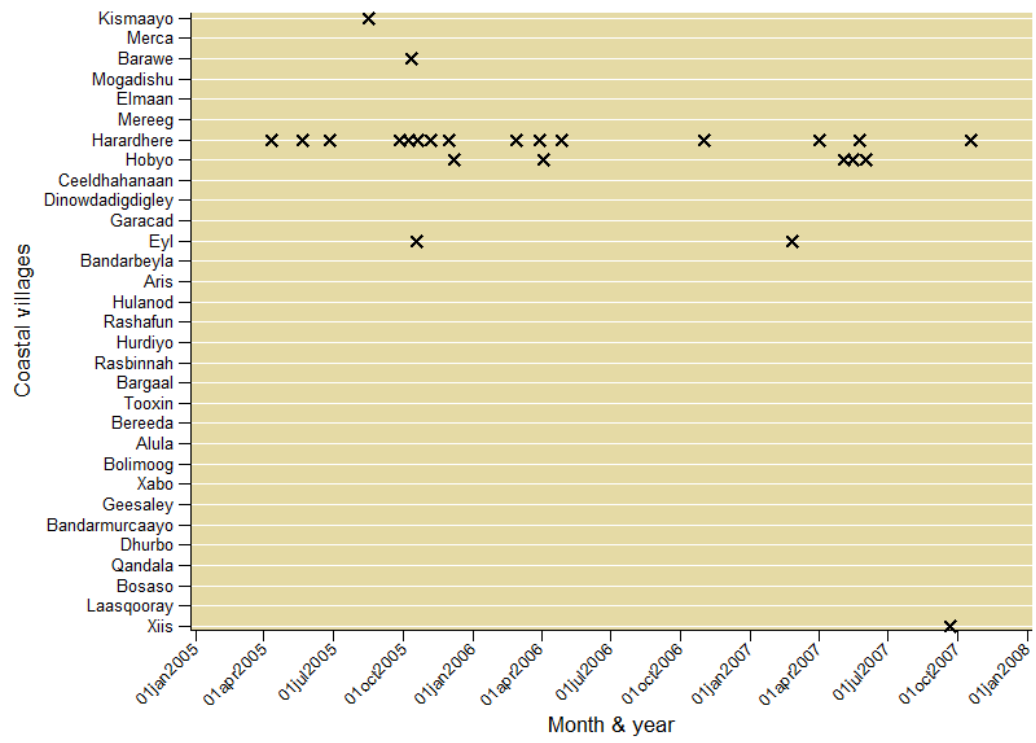

Figure 2: Anchorage of hijacked vessels, 2005-2007 $7^{42}$

In pointing to an amalgamation of protection rackets, predatory ex-security personnel and aggrieved fishermen, the coastguard hypothesis presents a luscious narrative. Yet, upon closer inspection, several core elements of the hypothesis appear speculative and incoherent. Firstly, protection rackets involving foreign illegal fishing trawlers were in existence in Puntland throughout the 1990s and the late 1980s. ${ }^{43}$ Smuggling, trafficking and protection of foreign vessels have in particular been practiced in Puntland's Bari region by the Ali Suleiman and Siwaqroon sub-clans in Qandala, Xabo and Alula along the Gulf of Aden coastline. ${ }^{44}$ These networks are still in existence. The Ali Suleiman clan, and notably the Biciidyahan and Awlyahan sub-clans within this clan, is noted for its dominance of fishing protection rackets. ${ }^{45}$ The author of this article witnessed first-hand in 2013 that Iranian fishing vessels, operating within Somali territorial waters, used privately contracted armed security personnel (PCASP) from Qandala. ${ }^{46}$ The coastguard hypothesis speculates that these same protection rackets fuelled the escalation of piracy. ${ }^{47}$ With regard to a mechanism, even the motive appears tenuous. Moreover, reviewing the evidence on piracy activities suggests no such development. The period 1991 to 2004, and even 2005 to 2007, saw a continuity of irregular, 
unorganised piracy in Puntland. Regarding a verdict on this dimension of the hypothesis, the mechanism is ambiguous, and the effect is not clear.

This ties into another dimension of the hypothesis, generally assuming that because some Puntland-based pirates were previously employed as coastguards, they also by consequence functioned as the pioneers of the earliest pirate groups. The assumption relies heavily on incidents such as the seizure of the Thailand-flagged fishing trawler Sirichainava 12. While this specifies a mechanism, the effect is absent, or at least not observable. Figure 2, showing the anchorage of hijacked vessels between 2005 and 2007, does not suggest that the Sirichainava 12 initiated a string of Puntland-based hijackings. Whereas Harardhere- and Hobyo-based pirates achieved a steady stream of hijackings over the two-year period, other anchorages (including Eyl) along the Puntland coastline exhibit the same irregular pattern that

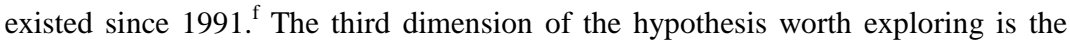
attempt to reconcile its narrative with that of Hansen's explanation for the outbreak of piracy. The next section explores this dimension in further detail.

\section{Timing of South Mudug piracy}

Current understanding of the origin of organised piracy in Somalia has been hampered by incautious treatment of the timing of the escalation. Neglectful demarcation of individual years has germinated into an ambiguous understanding of when and, consequently, how and why Somalia suffered its first outbreak of piracy. This negligence has been most obvious in the analysis of the appearance of pirate groups in Somalia's South Mudug region.

Bahadur, Marchal and Murphy frequently reference Hansen with regard to the escalation of Somali piracy, yet the latter's own study does not explicitly point to the coastguard narrative. Rather, Hansen's seminal study on Somali piracy argues that piracy before and after the outbreak was a matter of pre-mediation and relocation. The core claim articulated by Hansen is that Mohamed Abdi Hassan ('Afweyne') established a pirate group, the 'Somali Marines', in Harardhere in 2003. The pre-mediated choice of a village along the South Mudug coastline builds on Hansen's rationale that the area offered peace and stability, argued to be conducive towards the engagement in piracy. Hansen describes how Afweyne saw 'a good business idea' in pirate ventures, choosing Harardhere because it was

\footnotetext{
${ }^{\mathrm{f}}$ The last section of this article reports on the shift from this pattern (an adoption of the South Mudug piracy model), and towards a general escalation of piracy in Puntland in 2008.
} 
removed from the "fractions in the Somali civil war" ${ }^{48}$ Hence, no entities could hinder or 'tax' the pirate ventures. ${ }^{49}$

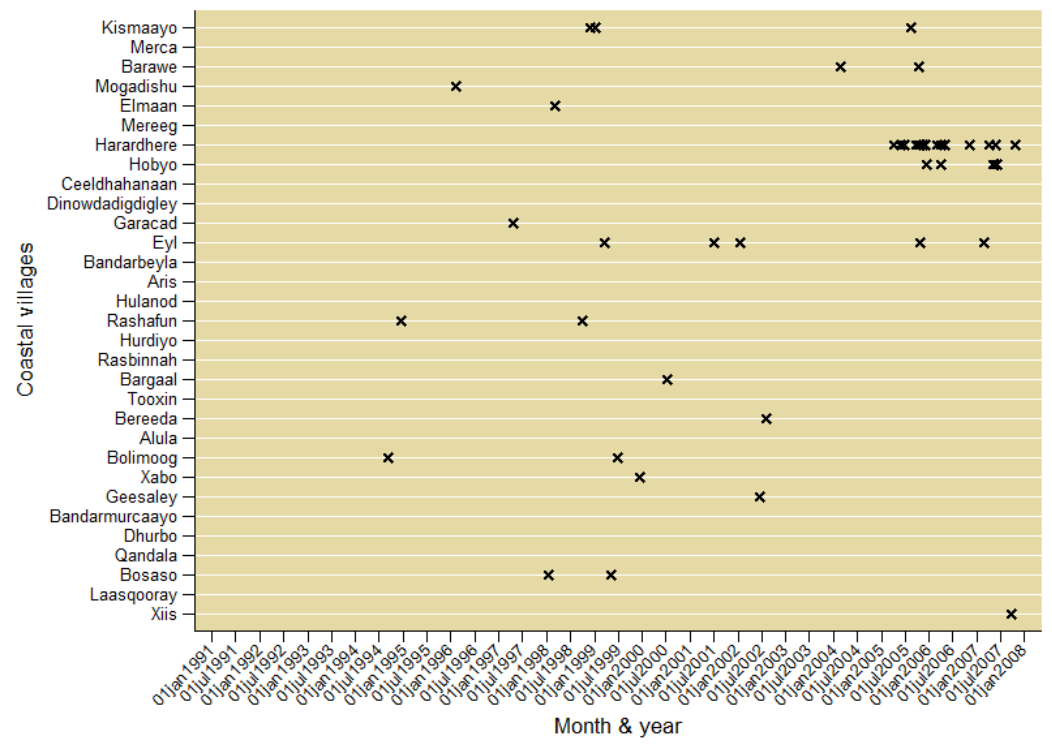

Figure $3^{\mathrm{g}}$ : Anchorage of hijacked vessels, 1991 to $2007^{50}$

The claim of pre-mediation is combined with a claim of relocation. When pirate attacks surged off the central coastline it was due to the active recruitment of 'pirate instructors' from the northeast. ${ }^{51}$ Bahadur vividly repeats the narrative:

As a boil festers before it bursts, the 2003-2006 Eyl-Harardheere alliance represented an incubation period for the Somali pirates, a time during which they gradually accumulated capital and experience, continually reinvesting ransom money in ongoing operations. ${ }^{52}$

${ }^{\mathrm{g}}$ Thirty-one coastal cities, towns and villages in Somalia are listed in Figures 2 and 3, from the fishing village of Xiis in Somaliland to the port city of Kismaayo near the Kenyan border. Tooxin (also spelled Tohen or Tohin) in position $11^{\circ} 45^{\prime} 1.71 " \mathrm{~N}, 51^{\circ} 15^{\prime} 18.55^{\prime \prime} \mathrm{E}$ is included in the list on account of its extreme proximity to (the south of) Cape Guardafui. Geographically, this fishing village hugs the coastal shipping route linking East Africa to the Gulf of Aden, yet it has hosted neither hijacked vessels nor pirate groups. The figure shows the anchorage of hijacked vessels, thereby excluding instances of looting where crew and vessel were left at sea. 
Piracy, according to Hansen, began in the Mudug region in 2003, and 'exploded' in 2004, leading to Mudug's first 'golden age'. ${ }^{3}$ However, the glaring absence of any pirate attacks off central Somalia in both 2003 and 2004 presents a significant challenge to this narrative. Indeed, as the next figure shows, claims of the existence of Afweyne's criminal pirate group in 2003 and 2004 are set in sharp relief by the absence of any crime. This discrepancy is revealing, and should force a rethink of the timing.

There is no data basis towards pinpointing an escalation of attacks in neither 2003 nor 2004. On the contrary, the years 2003 and 2004 suggest the continuation of the same type of irregular piracy observed since 1991. Hijackings in 2003 consisted of two incidents of on-board looting, and one incident of a fishing vessel, the South Korean-flagged trawler Beira 9, being taken near the southern town of Kismaayo. ${ }^{54}$ In 2004, there were a total of two attempts along the entire eastern coastline of Somalia. The first attack resulted in the hijacking of an Egyptian-flagged fishing vessel within the port waters of the southern town of Barawe, while the second attack targeted a British-flagged yacht near the northeast village of Ras Hafun. ${ }^{55}$

The 1991 to 2004 statistics concerning central Somalia are even more telling, suggesting that the South Mudug coastline experienced negligible maritime predation in the fourteen-year period prior to 2005. There were three registered piracy incidents off the Mudug coastline between 1991 and 2004, where the last incident had occurred on 16 November $2000 .^{56}$ Therefore, neither a gradual nor a sudden professionalisation of piracy from central Somalia is observable in the period 1991 to 2004. So why did Somalia's 'blue water' piracy originate from a coastline that had virtually no history of maritime predation? What explains the creation of pirate groups in Harardhere and Hobyo in 2005 ?

The present study proposes that Afweyne indeed was one of the early investors partaking in South Mudug pirate ventures. The Harardhere-based pirate group was ground-breaking in its entrepreneurial approach to maritime predation. However, previous studies have not been able to account for, nor have they sufficiently scrutinised, the time and context of this period of piracy. Why were attacks launched in 2005, and not in previous years? A fundamental weakness in previous treatment of the escalation is a lack of substantive discussion of the environment from where pirates operated. The following two sections situate the 2005 outbreak within abrupt and unprecedented changes to the security and socioeconomic climate of the South Mudug region. 


\section{South Mudug conflict}

The scale and importance of the conflict in the South Mudug region must be understood within the context of the local political geography. The area is inhabited by two main clans, the Suleiman and the Sa'ad, who are sub-clans of the Haber Gedir, which in turn is a sub-clan of the Hawiye clan. ${ }^{57}$ Absent governance in post1991 Somalia, the clan structure has remained the only stable political institution in many areas in the country. Social and economic behaviour therefore appear heavily coloured by clan considerations.

As seen in Figure 4, the Suleiman sub-clan is the dominant clan in and around Harardhere, which lies roughly twenty kilometres from the sea. Harardhere is both a pastoral and a fishing village, hosting fishermen who operate from lesser fishing camps by the coast, notably Ceel Gaan, Ceel Huur and Faax. Hobyo overlooks the sea, and has a permanent population that mainly consists of Sa'ad pastoralists and fishermen, although the area surrounding it is dominated by the Suleiman clan.

The 2004-2006 South Mudug conflict was intensely local, yet also violent and destructive for communities involved. The conflict has received little attention in the literature on Somalia, and non-existent treatment in studies examining Somali piracy. Investigation of the conflict reveals that it originated in disagreement over resources between the Suleiman and Sa'ad clans. ${ }^{58}$ The resource exhaustion in the South Mudug area appears to have been akin to a slow train wreck, where a series of ecological disasters culminated in warfare. Contemporary reports reveal that severe drought had exhausted livestock resources in the region, and by early 2004, the Suleiman and the Sa'ad were engaged in a low-level conflict over water access. ${ }^{59}$ Importantly, such disputes are not uncommon in Somalia, and have been a regular occurrence since at least the start of the civil war. ${ }^{60}$ Indeed, the two clans in question are known for their frequent resource disputes, but have nonetheless usually managed to settle these through traditional clan mediation.

In 2004, this traditional mechanism of mediation failed, with deadly consequences. Repeated stand-offs between Suleiman and Sa'ad pastoralists throughout 2004 led to deaths on both sides and an ensuing tit-for-tat cycle of revenge killings. ${ }^{61}$ Rather than return to normalcy, as has been the standard for such conflicts, the revenge killings escalated into assassinations of clan elders. Such assassinations targeted the very same individuals who traditionally have been responsible for mediating, and who normally prevent the violence from escalating beyond control. ${ }^{62}$ What began as a low-level conflict turned into warfare in November 2004 when several Suleiman clan elders were liquidated by rogue Sa'ad 
clansmen, who indeed had been on their way to a peace talks meeting with Sa'ad clan elders. ${ }^{63}$

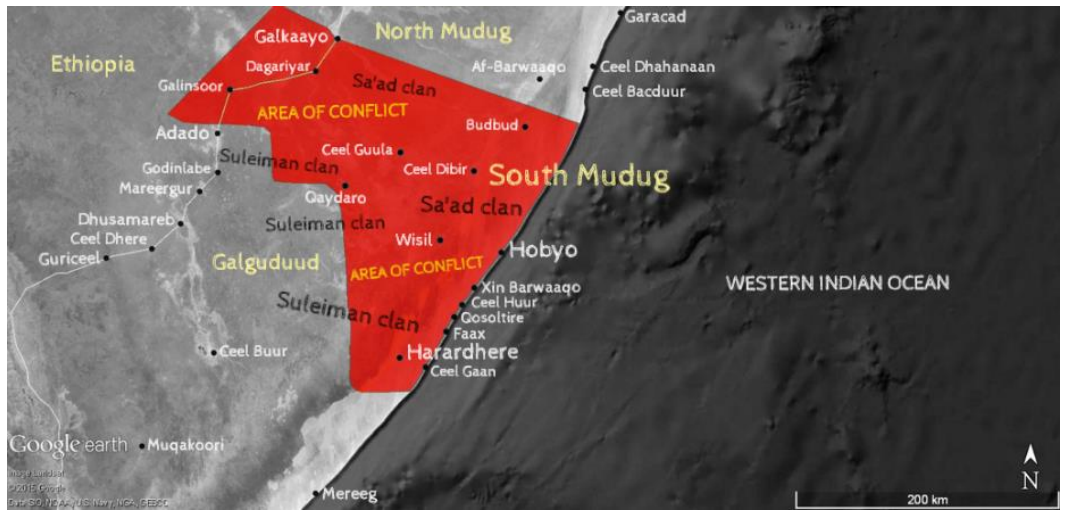

Figure 4: Overview of South Mudug region, 2004-2006 ${ }^{64}$

Between November and December 2004, the violence which had plagued the inland areas of South Mudug began spreading to the coastline around Hobyo and Harardhere. ${ }^{65}$ Both clans organised militias, and even clansmen residing in Mogadishu were providing additional funding, arms and equipment to strengthen their respective sides. Contemporary reports paint a picture of a conflict that quickly attained a sophistication higher than what could normally be expected from a local clan feud. ${ }^{66}$ Clan militia used satellite phones to share information on positions and movements, including tracking incidents of deaths, injuries and property destruction. ${ }^{67}$ Moreover, the cynicism of the fighting manifested itself through the targeting of religious students and teachers, entrenching animosity between the two clans. ${ }^{68}$ In December 2004, at least 130 people, including women and children, had been injured amidst fighting involving an estimated 500 clan militiamen. ${ }^{69}$ The fighting led to massive displacements of people, and by the end of the conflict, entire towns had been deserted. ${ }^{70}$ The final death toll between November 2004 and January 2006 was estimated at between 300 and 400 people. $^{71}$

The economic effects of the South Mudug conflict (discussed further in later sections) were severe and location-specific, leading to price spikes and local supply shortages. ${ }^{72}$ Since the onset of the fighting in 2004, the area separating Hobyo and Harardhere from the interior had suffered "huge material losses" ${ }^{73}$ The frontlines opening up in the bush land and desert areas along the coast cut Hobyo and Harardhere off from the only noteworthy road passing through central Somalia. ${ }^{74}$ Previous studies have argued that the relative peace and stability of central Somalia 
offered an environment conducive to the establishment of pirate groups. ${ }^{75}$ Examination of the local security environment reveals high and chronic insecurity over a fifteen- to sixteen-month period. Indeed, the first act of piracy coincided with one of the deadliest battles between the Suleiman and Sa'ad clans. ${ }^{76}$ The insecurity created by the conflict may, however, have been less consequential for piracy had the tsunami not occurred.

\section{The December 2004 Indian Ocean tsunami}

In the name of Allah, the city of Eyl was very peaceful and business was active. People got by and life was relatively good. The city's biggest business sector was fishing. Most of the money of fishing came from lobster and sharks. Businesses did flourish and many people benefited from the fishing business.

Mayor of Eyl speaking about the pre-tsunami era, 2014. ${ }^{77}$

The present investigation of the effect of the Indian Ocean tsunami on 26 December 2004 was motivated by the fact that it preceded the 2005 outbreak of piracy by a few weeks. What effect did the tsunami have on economic behaviour? Previous studies of Somali piracy, notably Percy and Shortland, Shortland, Dua and Menkhaus and Dua have often ignored the effects of the natural disaster. ${ }^{78}$ Other notable studies, such as Anning and Smith, Marchal and Murphy have acknowledged the event, but provided little or no analysis of its consequences for piracy. ${ }^{79}$ Most notable is Hansen, who appears to dismiss the effects of the tsunami, finding no changes in poverty levels for the coastal region. ${ }^{80}$ However, this assessment is inherently problematic as it does not build on any substantial empirical data, nor does it discuss the consequences of the tsunami on the economic behaviour.

The following section shows how villages strewn along the central and northeast coastlines were (and still are) heavily dependent on the artisanal fishing sector. ${ }^{81}$ This article examines the effect of the tsunami on the fishing sector and local livelihoods in the South Mudug region, as well as the northeast coastline. The short-term effect of the tsunami was to remove the main source of income for inhabitants in villages like Hobyo and Harardhere. Indeed, tsunami-induced destruction of the fishing sector was the most likely cause of the dissolution of fishing companies, and the subsequent formation of pirate groups in 2005 and later years. I argue that the long-term effect of the tsunami on the fishing sector was near terminal for Hobyo and Harardhere. Other villages in the northeast appeared to experience a gradual, downward spiral. Conclusively, the Indian Ocean tsunami on 
26 December 2004 may be labelled a 'black swan' event, significantly shifting the trajectory of the coastal economy of central and northeast Somalia. ${ }^{82}$

Breaking wave

Everyone ran, they ran as fast as they could up the hill. People were screaming and terrified. It destroyed our houses. It destroyed our fishing nets and boats. It destroyed everything. The next days people tried to catch fish and lobster for food but there was nothing in the sea. The sea died.

Clan elder in Puntland, 2007. ${ }^{83}$

The Indian Ocean tsunami wave on 26 December 2004 resulted from a magnitude 9.0 earthquake originating 250 kilometres southwest of the tip of Indonesia's Sumatra Island (see Figure 5). ${ }^{84}$ Clocking in as the world's largest in the past four decades, the earthquake formed a huge shock wave, or tsunami, consisting of the vertical displacement of hundreds of cubic kilometres of water. ${ }^{85}$ As observed in Figure 5, despite being 5000 kilometres from the epicentre, districts in central and northeast Somalia were among the worst affected in the Western Indian Ocean. The figure reveals the strength of the tsunami as it moved from the Eastern Indian Ocean and into the Western Indian Ocean, sustaining its high energy waves until the impact with the central and northeast coastline.

The worst-affected districts in Somalia (areas coloured black) received high and powerful tsunami waves (wave heights coloured a bright light green) similar to those in the seas around the earthquake fault line between Sumatra Island and the Andaman and Nicobar Islands (see Figure 5). On average, the run-up height of the waves on land was five to nine metres, which resulted in extensive flooding as far as 700 metres inland. ${ }^{86}$ As seen in Figure 5, the tsunami had the most significant effect on the 1300-kilometre stretch of coastline between Harardhere and Ras Hafun, covering the central and northeast coastlines of Somalia. By comparison, the northern Gulf of Aden coastline was virtually untouched, and southern Somalia suffered relatively minor damages. In total, an estimated 8000 coastal households were directly affected by the incoming waves. ${ }^{87}$ 


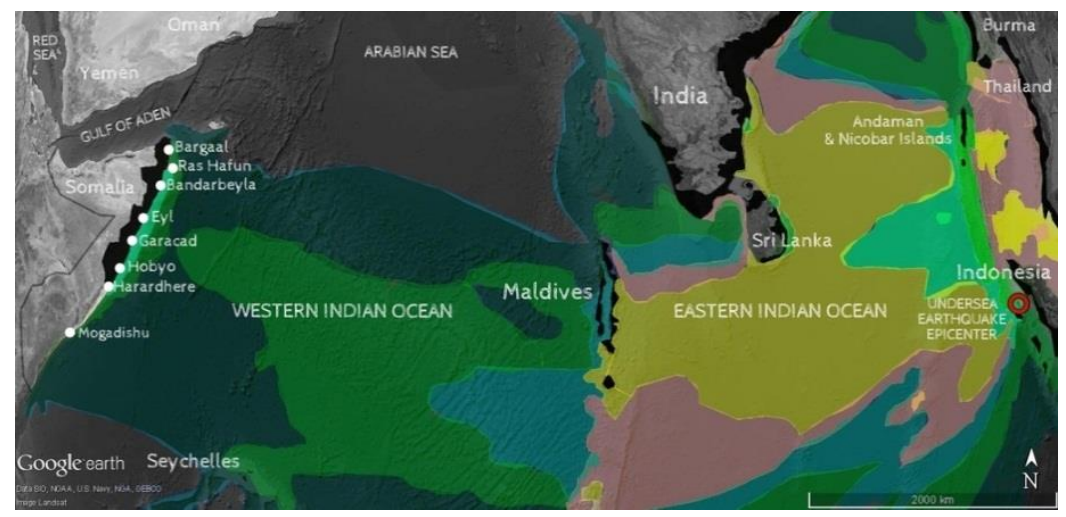

Figure $5^{\mathrm{h}}$. Indian Ocean tsunami, 26 December 2004: maximum wave heights and worst affected districts ${ }^{88}$

As evident in Figure 5, the United Nations Office for the Coordination of Humanitarian Affairs (UNOCHA) found the districts of Hobyo and Harardhere to be among the worst affected in Somalia. As seen in the figure, these districts suffered high-energy tsunami waves at the top end of the scale. A clan elder in Hobyo reported that the villages "were nearly wiped out". ${ }^{89}$ In Kulub village, to the north of Hobyo, more than 200 houses were damaged by the wave, while an estimated 44 fishing vessels were either lost or destroyed. The only existing storage facility along the central coast was obliterated by the tsunami wave, despite lying several hundred metres from the sea. Thousands of fishing nets, shark nets and lobster traps were destroyed. In a post-tsunami review of the central coastline, the destruction of

${ }^{\mathrm{h}}$ Coloration on the map denotes maximum wave heights in centimetre $(\mathrm{cm})$ as follows:

- $\quad$ bright green denotes $400+\mathrm{cm}$ (seen exclusively along the fault line axis from the epicentre and up towards the Nicobar and Andaman Islands);

- $\quad$ bright light green denotes $300+\mathrm{cm}$;

- yellow denotes $200+\mathrm{cm}$;

- $\quad$ pink denotes $100+\mathrm{cm}$;

- blue-green denotes $80+\mathrm{cm}$;

- green denotes $60+\mathrm{cm}$;

- $\quad$ dark green denotes $20+\mathrm{cm}$; and

- no coloration denotes $20 \mathrm{~cm}$ or less in maximum wave height.

Black coloration of coastlines denotes worst-hit districts of the Indian Ocean territories, including Somalia. Scale in bottom-right corner is set at 2000 kilometres $(\mathrm{km})$, corresponding to 1080 nautical miles $(\mathrm{nm})$. 
property was noted as "high and visible", and significantly higher than in southern Somalia. ${ }^{90}$

In northeast Somalia, the settlement of Ras Hafun suffered the single-most highest casualty toll for any village west of the Indian sub-continent, experiencing 19 deaths while 160 people went missing. The village suffered the destruction of 812 houses, and lost 162 out of 450 vessels. Bandarbeyla suffered 37 casualties, and there were 102 destroyed houses and 120 damaged fishing vessels. According to one fisherman, the water levels destroyed 40 per cent of the village's houses. ${ }^{91}$ In the Black Bay area, where Eyl is the dominant village, 95 bodies were recovered, while 80 persons suffered injury. Reportedly, 48 houses and 40 fishing vessels were either partially or entirely damaged. In total, an estimated 280 people died from the tsunami on the northeast coast, as well as the destruction of 630 fishing vessels, and 80 per cent of all fishing gear. ${ }^{92}$

Post-tsunami behaviour

The extensive damage incurred by the tsunami had a particularly destructive effect on the fishing sector, which represented around 75 to 80 per cent of all fishing income along the central and northeast coastline. Post-tsunami behaviour appeared to be largely defined by a broken fishing sector, and the disengagement of a large section of the fishing population. After the tsunami, an international humanitarian response was initiated for affected districts in Somalia. However, the South Mudug region remained unique in its isolation from aid efforts. Violent clan conflict and impassable, mined roads meant that relief materials aimed to cushion the impact never made it to the coastal areas around Hobyo and Harardhere. ${ }^{93}$ A clan elder in Hobyo recalled bitterly in an interview that "when the tsunami struck, nobody helped". ${ }^{94}$

Villages outside the South Mudug region, including Kulub and Garacad in the North Mudug region, received immediate relief for the first period after the tsunami. ${ }^{95}$ In the first weeks after 26 December 2004, the World Food Programme (WFP) provided hundreds of metric tons of emergency food aid. ${ }^{96}$ The WFP, the United Nations International Children's Emergency Fund (UNICEF), Save the Children, the Norwegian Church Aid (NCA) and a host of other aid organisations provided equipment, vessels and housing. Fishing-related equipment were distributed, and a few fishing vessels were provided to a handful of villages. ${ }^{97}$ The Food and Agriculture Organization (FAO) provided basic engine repair training for fishermen, and training courses in the handling and processing of fish. ${ }^{98}$ Efforts were 
also directed towards the organisation of the fishing sector with the establishment of fishermen associations in Ras Hafun, Bandarbeyla, Eyl and Garacad.

Despite initial efforts, the actual long-term effect of the aid effort appeared temporary and ultimately insufficient. While humanitarian aid offered to the northeast provided short-term relief, a district official in Eyl explained that it only temporarily stabilised the economic decline. ${ }^{99}$ According to the Mayor of Eyl,

There were a lot of projects undertaken after the tsunami. There were a lot of aid agencies that did humanitarian projects during that time. What was planned for the tsunami victims, and what had reached [us] were two very different images. Some houses didn't really last, they became dilapidated a few years later, either due to the bad quality or poor care. So that's how it was. ${ }^{100}$

Another official in Eyl, a member of the District Council, noted that Then the industry was hit by the tsunami. The tsunami played a big role in destroying the livelihoods and the people did not get good recovery. ${ }^{101}$

In the northeast fishing village of Aris, a settlement perched atop a cliff overlooking a white beach and the Indian Ocean, inhabitants used to live in huts on the beach prior to the tsunami. These living quarters were washed away by the tsunami. After the event, Save the Children constructed concrete housing units to replace the destroyed beach homes. However, conversations in 2014 with fishermen in Aris revealed that many of the houses had remained uninhabited. Fear of the sea has persisted in this community, and most of the houses are now only used by the fishermen as storage rooms during working hours. To feel secure, these fishermen have opted to live in shacks at the higher elevations of the surrounding cliffs. Some of the original recipients have even sold the houses, and left Aris altogether. ${ }^{102}$ The case of Aris indicates the complexity of the coastal reaction to the tsunami disaster. Many households emigrated from the coastline, and the area may have experienced a 'brain drain' of fishing expertise in the subsequent emigration.

Several respondents claimed that those who stayed faced a fishing sector that was much less productive than previously. ${ }^{103}$ Prior to the tsunami, fishermen along the coast had invested heavily in the sector, and much of this equipment, including portable fridges and nets, were stored on the beach when the tsunami impacted. ${ }^{104}$ One district official in Eyl reported -

Nowadays people cannot afford to buy vessels and gear from Dubai because they do not have capital. The engines that they are using 
right now are engines that they bought during the profitable days of lobster trade. So, that is how fishing used to be. ${ }^{105}$

Effects of the tsunami on the fishing economy were not limited to the flight of inhabitants and the destruction of physical capital, but the marine environment inhabited by fish and lobsters species also suffered. Prior studies on Somali piracy have mentioned the depletion of marine resources in terms of overfishing either by foreign trawlers or the local population. Field research by the author suggests that inadequate attention has been devoted to the effect of the tsunami on the coastal seabed. This appears to have had a direct consequence on the ability of coastal fishermen to sustain their livelihood. Respondents in several of the coastal villages noted how the tsunami had changed the geology along the coast -

What is apparent is that many different types of fish, and a good percentage of lobster, that were found before the tsunami, are not found currently. The tsunami destroyed the homes of marine life, such as the caves and holes in which lobsters lived, which were buried with sand. A very big decline that is hard to imagine and which is very obvious occurred. Many fishermen left the fishing industry for other means of support such as herding livestock and searching for work in urban areas. ${ }^{106}$

The Mayor of Eyl explained that by early 2006, the price of lobster had shrunk from US\$30 to US\$15, while shark fins had dropped from US\$100 to US $\$ 50 .{ }^{107}$ The price fall appears to be partly attributable to the inferiority of the marine products sold by fishermen subsequent to the tsunami. Destruction of fishing assets led to a lack of proper storage equipment, and fishermen arriving at the beach in the scorching Somali heat struggled to preserve their catches for export.

In the long term, the post-tsunami delivery of fishing nets, hooks and lines appear, albeit unintentionally, to be treatment of symptoms rather than a sustainable solution. An inhabitant in Bandarbeyla lamented -

Truthfully the natural disaster that hit Bandarbeyla in 2004 had huge problems that people still haven't recovered from. People became internally displaced after the output of the fishing industry declined, homes were destroyed, expensive equipment such as skiffs, nets, fishing boats [were] all destroyed. ${ }^{108}$

The decline in villages like Eyl and Bandarbeyla was gradual, and suggests both short-term and long-term consequences on the coastal economy. The most notable structural change is found in the dismemberment of fishing companies (artisanal). In the context of individual villages along the coast, a fishing company 
can be anything from an elementary association of shareholder fishermen to a single-owned structure financed by businessmen of moderate wealth. ${ }^{109}$ These fishing companies, of which the former are the most common, have offered an important organising structure for everyday economic life. A fisherman in Eyl explained -

Fishermen are very organized, almost like a government. We are usually around $6,7,8,9$ or 10 , depending whatever manpower is required. So there is one person that leads the team. And I've held every job in this group from the lowest rank to the highest rank. ${ }^{110}$

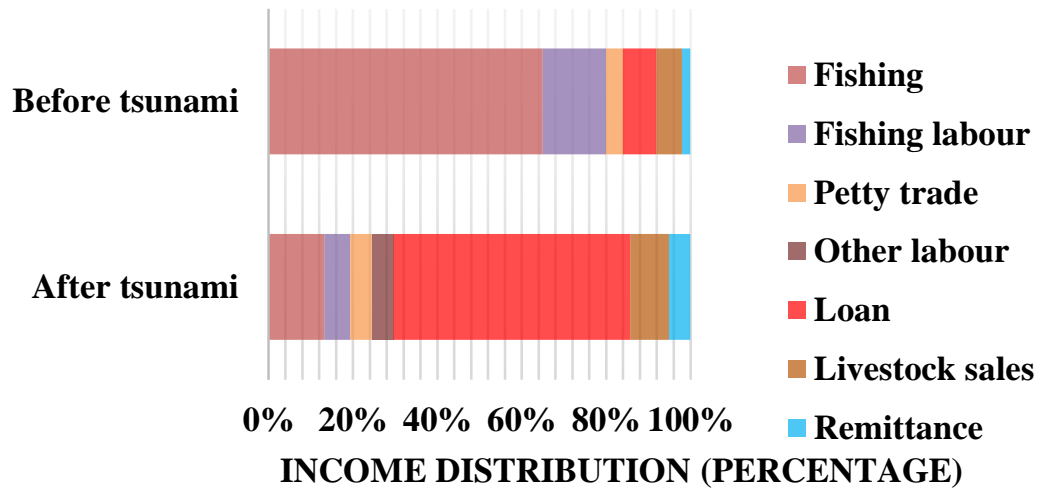

Figure 6: Income distribution before and after the tsunami of 26 December $2004^{111}$

Weldemichael found that these fishing companies along the coast "never recovered from their losses" after the tsunami. Several fishing companies simply went bankrupt, and those that remained "continued to operate on massive (sic) deficit". ${ }^{112}$ Three lobster companies operating along the northeast suffered a 50 per cent decline in lobster export figures in the aftermath of the tsunami. ${ }^{113}$ The Mayor of Eyl noted -

Private enterprises made huge sums of money from fishing up until the tsunami in 2004. It was not uncommon to see fishermen with just a net and a skiff achieving returns of US\$3000 to US\$5000 from just one fishing season. Fishermen with better equipment such as a midsize fishing boat could make up to US\$10,000 to US\$15,000 in one fishing season. Leading up to the tsunami fishermen began investing into the fishing industry, but shortly after the tsunami hit, which wiped out their investments. ${ }^{114}$ 
The comments by the Mayor of Eyl suggest a level of asset loss that forced many companies into insolvency, which, as a consequence, resulted in a massive lay-off of fishermen. The dependency on fishing incomes as livelihoods along the coast is well illustrated in Figure 6, and prior to the tsunami, around 95 per cent of coastal food consumption came from fishing or fishing-related income.

Before the tsunami, only 8 per cent of income was derived from loans, yet after the tsunami, roughly 20 per cent of income came from fishing, while 55 per cent came from loans. ${ }^{115}$ High debt levels and food insecurity forced around 20-30 per cent of the total population between Garacad and Ras Hafun to emigrate, many of whom headed to urban centres like Galkaayo, Garowe and Bosaso. Testimonies from Mereeg (in the Galguduud region to the south) suggest that many fishermen residing in Hobyo and Harardhere also disengaged, and left the area to seek employment elsewhere. ${ }^{116}$ Six months after the tsunami, less than 30 per cent of the fishing sector labour stock had resumed fishing activities. ${ }^{117}$

\section{First outbreak of Somali piracy}

The review of the Indian Ocean tsunami of 26 December 2004 suggests that a large portion of the coastal population was forced to disengage in 2005. The coastal areas depopulated in the period after the event, and left remaining inhabitants in a poor economic state. Was such an environment conducive to piracy? The present study found an explicit link between a broken fishing sector and the creation of pirate groups. The study argues that the first pirate venture launched from Somalia in 2005 was a simple adaptation of a pre-existing coastal business. The pioneering innovation of Afweyne's pirate group in the form of the South Mudug piracy model offered a simple blueprint for viral predation. The following section discusses the outbreak of piracy in the period 2005 to 2006, and provides a context for its re-emergence in early 2007.

The South Mudug piracy model

Understanding pirate activities in 2005 should necessarily focus on the pioneering role of Mohamed Abdi Hassan (aka 'Afweyne'), and the characteristics of what may be called the 'South Mudug piracy model'. Afweyne's 'good business idea' was not launched in a stable area of Somalia, but quite literally along the fault line of the South Mudug battlefield. ${ }^{118}$ Testimony from an informant from the Suleiman clan in Harardhere reveals that on the eve of Afweyne's piracy career, he was a shareholder in a company that specialised in fishing and livestock. ${ }^{119}$ The company appears to have been on the high end of business enterprises operating in 
the Harardhere area.The company possessed several 'technicals', i.e. customised vehicles armed with light weaponry, serving to protect its assets. ${ }^{120}$ Such a sophisticated protection regime is not common practice among coastal fishermen. ${ }^{121}$ The company owned several smaller vessels that engaged in shark and lobster fishing, and exported fish products and livestock to the Arabian Peninsula. In 2005, the activities of the company ceased when it suffered a substantial asset loss in the fishing sector. ${ }^{122}$ Based on this testimony, Afweyne's company appears to have endured the same tsunami-induced loss that other fishing companies suffered.

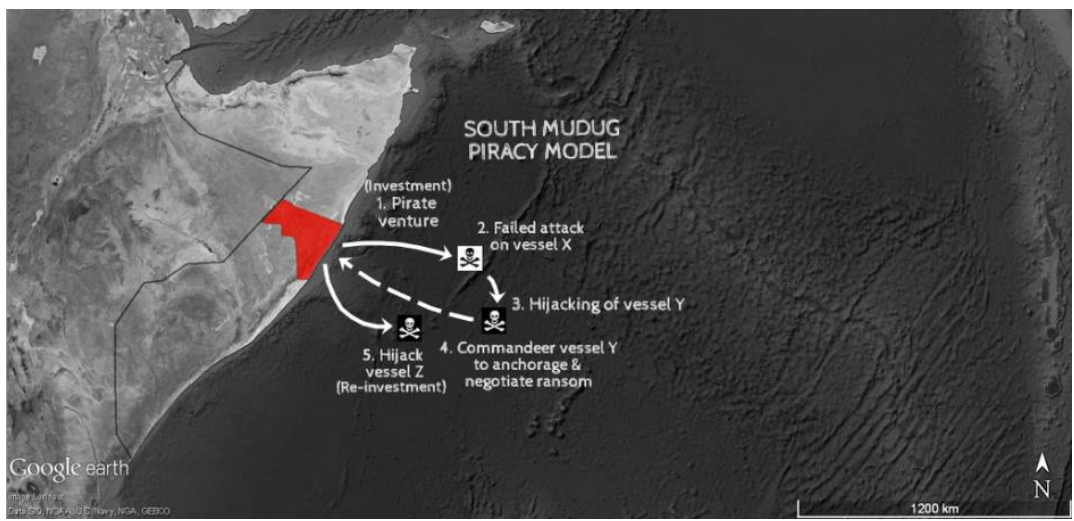

Figure $7^{\text {i}}$ : South Mudug piracy model ${ }^{123}$

Concurrent with this income loss, the shareholders of the company formed the first pirate group. ${ }^{124}$ The innovation offered by Afweyne's company was the establishment of the South Mudug piracy model. A basic overview of the model can be observed in Figure 7. Moreover, the model became the gold standard after which pirates engaged in maritime predation after $2005 .^{125}$ The model pioneered by Afweyne's company built on a shareholder structure, where several individuals came together to finance the pirate venture. ${ }^{126}$ This did not limit later pirate ventures from operating on the basis of other financial arrangements. Rather it proved to potential pirates, evident from the 2008-2009 pirate attacks, that whereas individually they could not harness the resources for a venture, they could collectively pool their resources together in return for a potentially lucrative payoff. ${ }^{127}$ As such, just as small tightly-knit clan groups were a recurring

\footnotetext{
${ }^{\mathrm{i}}$ Black pirate symbol denotes hijacking; white pirate symbol denotes pirate attack. Scale in bottom-right corner is set at 1200 kilometres $(\mathrm{km})$, corresponding to 648 nautical miles $(\mathrm{nm})$.
} 
characteristic of fishing groups and companies, they became the main mobilising vehicle for pirate ventures in Somalia after 2005.

The simplicity of the South Mudug piracy model was revealed in the earliest attacks committed off the central Somali coastline (see Figure 8). The first pirate attack, against the Trust Dubai, was committed at a record-breaking 200 nautical miles from the coast. The attack, as reported by the ship, was perpetrated by a group of six pirates. Despite their small numbers, the pirates were armed with 'guns and grenades'. ${ }^{128}$ After pursuing the ship for a little less than two hours, the pirates attempted to board, but were repulsed by the ship's increased speed and evasive manoeuvres. A mere eleven days later, an attempt was made on the bulk carrier Tim Buck. It too managed to escape its pursuers, although the master of the ship died from a heart attack. ${ }^{129}$ A few hours later that day, pirates managed to board successfully and hijack the gas carrier Feisty Gas. ${ }^{130}$ After completing the hijacking, the pirates brought the ship to the shores near Harardhere. ${ }^{131}$ A month later, pirates hijacked the Reef Malindi, which was also commandeered to Harardhere.

The third hijacking by Harardhere-based pirates involved the WFP cargo vessel $M V$ Semlow on 27 June 2005. ${ }^{132}$ When the MV Semlow arrived on the coastline, it was taken to the area between Faax and Ceel Gaan. ${ }^{133}$ The two fishing camps lie parallel to Harardhere, situated $20 \mathrm{~km}$ further inland. These would become the routine locations at which Afweyne's pirate group anchored their victims. After the capture of the $M V$ Semlow, Afweyne personally commented that the vessel was not taken for ransom, but to defend the seas from illegal fishing and toxic waste dumping. ${ }^{134}$ Shortly thereafter, a clan elder in Harardhere announced that the $M V$ Semlow would be prosecuted for illegal entry into Somali waters. ${ }^{135}$ Indeed, contrary to their justifying claims, Afweyne's pirate group ended up receiving a ransom payment of US\$100 000 for the vessel's release. ${ }^{136}$

The hijacking of the MV Semlow was followed by a string of new attacks. Piracy activities coincided with continued fighting between Suleiman and Sa'ad clan militias, which left 43 people dead between late 2005 and early $2006 .{ }^{137}$ Between late 2005 and early 2006, a new group had begun operating from Hobyo, and one of its victims was a fishing trawler captured 55 nautical miles off the coast. The South Korean-flagged trawler Dong Won No. 628 had been fishing tuna when on 4 April 2006, it was haplessly besieged, boarded and hijacked by a single pirate skiff. After the pirate group had commandeered the trawler and its 25-man crew back to Hobyo, one of the pirates charged that the ship had been fishing illegally. ${ }^{138}$ A Hobyo clan elder declared that the ship would be 'fined' for its illegal activities. ${ }^{139}$ 


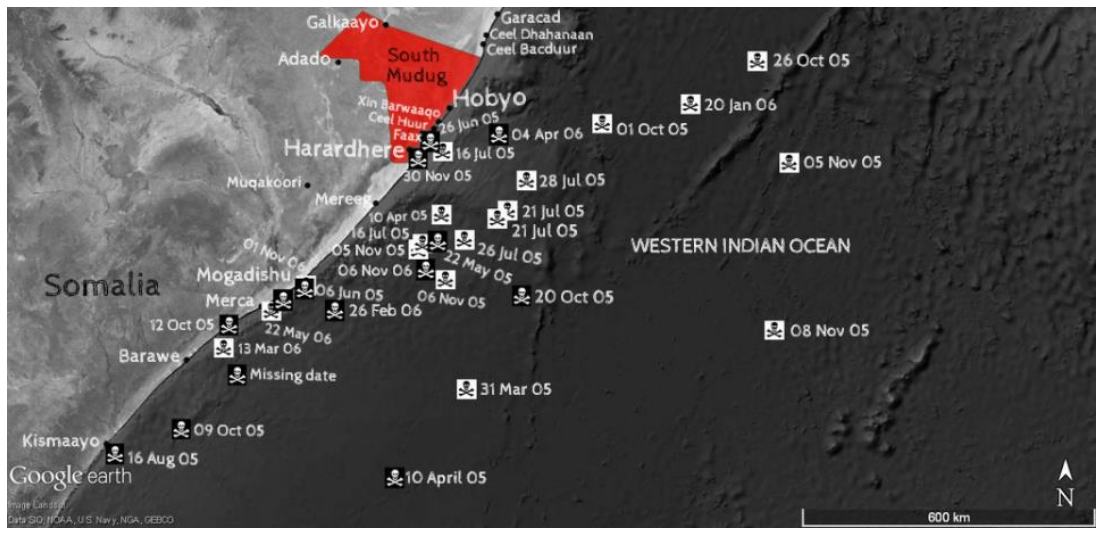

Figure $8^{\mathrm{j}}$ : Pirate incidents off central and southern Somalia, March 2005 to May $2006^{140}$

Figure 8 provides a graphic depiction of the pirate-infested waters off the South Mudug region up until May 2006. Indeed, by January 2006, at least 100 mariners were held captured aboard vessels anchored off the South Mudug coastline. At least half of all pirate attacks targeted vessels that were more than 100 nautical miles from the coastline. November 2005 saw the use of a mother ship, significantly increasing the range of attacks. ${ }^{141}$ During this month, two attacks occurred at distances far exceeding 200 nautical miles, and one approaching 400 nautical miles (or roughly half-way to the Seychelles island archipelago). The number of monthly attacks remained at a consistent level throughout most of the period, although a decline in attacks (but not the rate of hijacking) is apparent after February 2006. The capture of the Panama-flagged tanker Lin 1 and the South Korea-flagged trawler Dong Won No. 628 within the span of a few days could have signalled that piracy was spiralling out of control. Yet, only a few weeks later, pirate skiffs melted away from the area, and the South Mudug coastline went quiet. The wave of attacks that had occurred over a 13-month period ended as quickly as they had begun. Why did piracy activities cease? And why did they resume with such vitriol in early 2007 ?

${ }^{\mathrm{j}}$ Black pirate symbol denotes hijacking; white pirate symbol denotes pirate attack. Scale in bottom-right corner is set at 600 kilometres $(\mathrm{km})$, corresponding to 324 nautical miles $(\mathrm{nm})$. Scale in bottom-right corner is set at 600 kilometres $(\mathrm{km})$, corresponding to 324 nautical miles $(\mathrm{nm})$. 


\section{Dormant piracy model}

The cessation of pirate attacks in 2006 has commonly been explained in relation to the emergence of the Islamic Courts Union (ICU) in Somalia. ${ }^{142}$ The rule by the ICU consolidated security in central and southern Somalia in the latter half of 2006. According to Hansen, the strict Islamic code enforced by the ICU in Hobyo and Harardhere 'ended piracy'. ${ }^{143}$ However, data on the local environment in the South Mudug area for this period suggest that the matter is more complex than previously perceived. The first observation is that the decline and eventual cessation of pirate attacks occurred prior to ICU rule. ${ }^{144}$ Indeed, the timing may be more persuasively linked to local security improvements unaccounted for in the extant literature. Positive security developments in the Hobyo and Harardhere area began with a comprehensive peace process between the Suleiman and Sa'ad clans. The most significant accomplishments of this process took place in spring $2006 .{ }^{145}$

On 25 February 2006, the Suleiman and Sa'ad clans signed a ceasefire, ending the major battles that had been waged since late 2004. By April 2006, clan militia were disengaging and roadblocks were removed. Suleiman and Sa'ad clan elder meetings were held at Ceel Huur, a fishing village situated almost exactly halfway between Hobyo and Harardhere, where the focus was on sharing water and grazing resources. ${ }^{146}$ Notably, the same village had hosted the anchored MV Semlow roughly one year previously. The ceasefire also permitted a re-opening of the road to Galkaayo, allowing Sa'ad and Suleiman fishermen to resume some level of activity. ${ }^{147}$ By May 2006, pirate attacks had ceased entirely. When the ICU arrived in Hobyo and Harardhere in August 2006, there had not been a pirate attack launched from the region in over two months. ${ }^{148}$

At Hobyo, heavily armed ICU militia spoke to clan elders of the village, before being allowed to enter. ${ }^{149}$ The peaceful manner in which the village submitted to the organisation is a function of the clan constellation of the ICU. While the ICU officially was a movement of Mogadishu-based Islamic courts, it was also essentially a Haber Gedir clan project, of whom the Suleiman and Sa'ad are subclans. Notably, both sub-clans exercised control over their own Mogadishu-based courts. Viewed through this lens, the arrival of the ICU merely reinforced a period of stability for the Haber Gedir clan as a whole. ${ }^{150}$ By August 2006, the South Mudug conflict had been resolved, and the region was ruled by a single political entity. How did this stability affect pirate activities? 
Pirate coast

The low number of incidents between May 2006 and December 2006 confirm the absolute fall in piracy during the last three quarters of 2006. It also speaks of a complementary relationship between the reconciliation of the Suleiman and Sa'ad and the stabilising effect of the short-lived ICU polity. However, the state of the economy along the coast casts serious doubts on the extent to which small, incremental increases in security were enough to dissuade piracy in the medium to long term. The situation in Hobyo by mid-2006 does not suggest a community rebounding from conflict, but one on the fast track towards an irreversible decline. ${ }^{151}$ As such, the present study proposes that the South Mudug piracy model merely lay dormant during a short interregnum.

Evaluating the merits of this proposition necessitates a look at economic behaviour along the central coast in late 2006. The most notable observation on Hobyo is that maritime trade appears to have ceased completely by mid- 2006 . Dhows were no longer arriving from regional ports, and this situation remained unaltered for the next few years. ${ }^{152}$ Many former residents had fled due to the South Mudug conflict, leaving only a few hundred individuals in the village. ${ }^{153}$ The disengagement of fishermen from Hobyo in 2005 had sent some up the coast to the area bordering North Mudug, while some others relocated to Mereeg along with fishermen from Harardhere. ${ }^{154}$ A Sa'ad clansman visiting the village in August 2006 noted that the once-thriving Hobyo was "quiet and depressed". ${ }^{155}$ Despite the cessation of the hostilities in the area, Hobyo appeared to have virtually broken its back.

Whether they were fishermen is uncertain, but on 1 November 2006, pirates from Hobyo reappeared in the seas off Somalia. Some weeks later, the invasion of Somalia by Ethiopian forces resulted in the complete and surprising dissolution of the ICU polity. ${ }^{k}$ Concurrent with the organisation's territorial control evaporating followed a steady uptake in the frequency of attacks. Once the first vessels had been successfully hijacked and anchored safely along the coast, the predation business appears to have gone viral. Between January and June 2007, pirates from Hobyo and Harardhere had attempted to board nine individual vessels, and managed to hijack six of them. ${ }^{156}$ In all, the two villages were responsible for hijacking at least 75 different vessels between 2005 and 2012, averaging one hijacked vessel per every passing month. ${ }^{157}$

\footnotetext{
${ }^{\mathrm{k}}$ By late December 2006, the ICU had lost significant swathes of land to Ethiopian forces.
} 
Analysis of the first outbreak of Somali piracy between 2005 and 2006 clearly accentuates the extent to which the 2007 piracy practices were a mere continuation of a new coastal business model (piracy). The South Mudug model served as a simple predatory framework upon which new groups were established. However, the present study has shown how engagement into piracy must be viewed within the context of unprecedented disengagement from previous coastal livelihoods. Over the long term, the effect of the Indian Ocean tsunami on 26 December 2004 therefore appears particularly important in relation to the intensification of piracy activities. As shown, the fishing sector represents the single most important livelihood for villages along the central and northeast coastline.

For Hobyo, the transformation appears extreme. Interviews with two eyewitnesses who were present in Hobyo in 2008 and 2010 illustrate how the former fishing village had undergone an extraordinary metamorphosis. An eyewitness that visited Hobyo in 2008 re-called how it had become -

[...] entirely a pirate village. Everything, and everyone, was set up in support of piracy. The exception was a few older fishermen who were still active. It may have been because they couldn't participate in such a frail, ageing condition. ${ }^{158}$

Another eyewitness visiting Hobyo in 2010 recalled how the village appeared lost on the coast, remarking that "it was the end of the world". ${ }^{159}$ The road from Hobyo to Galkaayo was observed as completely void and with "no economic activity". 160

The metamorphosis into pirate lairs by other tsunami-affected villages, notably Eyl, appears to have begun in late 2007, and escalated in 2008. The Indian Ocean tsunami on 26 December 2004 laid important groundwork in terms of destroying the fishing sector in Eyl. However, high levels of insecurity appeared to be an imperative second condition for piracy to thrive, and for nearly two years (2005-2007), Northeast Somalia did not host the necessary levels of insecurity to foster large-scale predation. ${ }^{161}$ The escalation of piracy along the northeast coastline between 2007 and 2008 must, therefore, have occurred within the context of a sharp deterioration of the security climate - and there is strong evidence to suggest that this occurred.

Throughout 2007, the northeast region of Somalia, previously an oasis of relative calm, began a descent towards insecurity. The mechanisms for the deterioration of the environment are in no doubt complex, yet there appears to have been at least three factors at play. Puntland's localised conflict with Somaliland, to the area west of Garowe, led to a serious drain on the financial strength of the 
state. ${ }^{162}$ The most dramatic consequence was Puntland's failure to fund services and pay its state-wide security forces. ${ }^{163}$ The second factor was a result of the Ethiopian invasion of Somalia in December 2006. After crushing the ICU militia in January 2007, Ethiopian forces arriving in Mogadishu attempted to create a political and no less physical space for the embedded entourage of the Transitional Federal Government (TFG). However, intense animosity between clan factions, and towards the Ethiopians, turned Mogadishu into a battleground. ${ }^{164}$ Between 200000 and 300000 people were displaced amidst ferocious shelling and fighting in the capital. ${ }^{165}$ What followed was large-scale destruction of property and assets, and a massive nationwide displacement of people. Throughout 2007, Puntland received an influx of internally displaced people (IDPs) for which it was entirely unprepared. Tens of thousands of IDPs from the southern and central areas around Mogadishu fled to Galkaayo and Garowe, and notably, the coastal areas. ${ }^{166}$ Finally, a third ingredient towards insecurity was Puntland's spiralling hyperinflation, which significantly reduced the value of the Somali shilling, and by consequence undermined the local purchasing power. ${ }^{167}$

How did this affect the security situation? Figures on road banditry and kidnappings suggest predatory activity increasing at an alarming rate in 2007 and $2008{ }^{168}$ The number of car hijackings in Puntland, as reported by its police force, rose from 92 in 2006, to 172 in 2007, and reached 180 car hijackings in 2008. ${ }^{169}$ Kidnappings were attempted, notably against non-governmental organisation (NGO) workers visiting Maraye village, a few kilometres north of Eyl. Several NGOs operating in the Nugaal region began experiencing increased incidents of material and equipment theft while transiting through villages. ${ }^{170}$ The situation only worsened in April 2008, when the State of Puntland ceased paying wages to its security forces, and was reduced to controlling the north-south axis road between Galkaayo and Bosaso. ${ }^{171}$ Already suffering from a broken fishing sector, the coastal communities were therefore in a position of extreme vulnerability towards engagement in predatory activities, both onshore and at sea. As discussed extensively previously in this article, the northeast coastal communities were suffering from high debt levels and widespread unemployment after the dissolution of fishing groups and companies.

The problem of piracy in Somalia, then, appears heavily intertwined with the state of the coastal economy, and the fishing sector in particular. This study argues that fishermen in Hobyo and Harardhere, and later along the northeast coast, might have been more immune towards recruitment into an uncertain and violent activity if the fishing sector had afforded some level of competitiveness. Moreover, communities along this littoral may perhaps have been able to punitively sanction 
and withstand the arrival of outsiders seeking to partake in a highly lucrative criminal activity. Low immunity therefore appears to be linked with an inability to subsist off the seas. As such, the study concludes that the tsunami significantly altered the relationship between coastal communities and the sea.

\section{Concluding remarks}

The present study attempted to offer critical and new insight into the origin of organised piracy in Somalia. The first groups purely dedicated to piracy in Somalia, from Harardhere and Hobyo, were not formed due to a decade-long struggle against illegal fishing. Nor were they the result of former coastguard employees banding together to predate on the high seas. Neither were pirates the inevitable spark on a long-burning fuse of poverty. The 2005 outbreak appears to have been borne out of a sudden implosion of the economic and security environment of central Somalia's South Mudug region.

An assessment of the first months of the outbreak reveals two distinct forces at work. The central Somali region of South Mudug was not a stable area in 2005, but was suffering from the most violent conflict since the collapse of the state in 1991. Would-be pirate villages Hobyo and Harardhere lay in the heart of the area of conflict, hosting clashes between Suleiman and Sa'ad clan militia. However, conflict along the Somali littoral was not new, and had been a prominent feature of areas further south in Somalia in the preceding decade.

Maritime predation did not evolve out of clan conflict and insecurity alone, but was possibly the result of the freak event of the Indian Ocean tsunami on 26 December 2004. The fact that there was negligible maritime predation from the South Mudug region prior to 2005 suggests a surviving, perhaps even relatively healthy coastal economy. As shown, opportunistic attacks on passing vessels were rare. While the invasive behaviour of foreign fishing trawlers is well documented, and re-iterated in many of the fieldwork testimonies, this did not translate into dedicated pirate groups. ${ }^{1}$ For coastal communities, the Indian Ocean tsunami on 26 December 2004 was as catastrophic as it was unprecedented. The tsunami blitzed the fishing sector, leading to widespread disengagement from a livelihood on which many coastal communities were unilaterally dependent. By destroying the dominant livelihood of central and northeast Somalia, the tsunami contributed to a predatory environment that has served a decade of ransom piracy.

\footnotetext{
${ }^{1}$ Grievances, it seems, are not reliable vehicles of mobilisation.
} 
Critical analysis of the local environment in which piracy occurs enables the scholar to better understand the rationale of pirates. However, the task of analysing the local environment is difficult to undertake given the inaccessibility of Somalia's isolated littoral strip. By focusing the prism on individual villages it is arguably easier to gauge the spectrum of factors that are conducive to producing pirates locally. Far too little has been written about the socioeconomic and security situation of the area where the first outbreak of piracy occurred. This may be a consequence of a neglectful treatment of time, leading to an ambiguous understanding of when, and by consequence why, attacks first began.

The data wilderness of Somalia is a significant challenge to research on Somali piracy. Here the scholar wears the cloth of a wandering nomad, occasionally spotting a small rock or pebble, seeking to chisel out another piece of information. With this in mind, the original aim and main contribution of the study were empirical. Fieldwork testimonies and contemporary reports have yielded new data on the coastal communities in central and northeast Somalia. These are however only snapshots of the coastline. Further research into the outbreak of Somali piracy is required. Researchers studying Somali piracy must, for the sake of the credibility of the field, undertake the arduous task of establishing a more accurate profile of the local coastal environment in which piracy thrives. Similarly, further research in the field must investigate the circumstances in which coastal communities disengage from piracy.

\section{Endnotes}

${ }^{1}$ I thank my research assistant 'Muse', who carried out many of the coastal interviews on my behalf; the crew of Royal Danish naval vessel HDMS Esbern Snare for generously allowing my participant observation aboard the ship during its anti-piracy operation off the Horn of Africa; my supervisors, Jens Ringsmose and Thomas Mandrup, for their invaluable guidance; and two anonymous referees for constructive comments and discussion. I am grateful for the hospitality of the inhabitants of the Mudug, Nugaal, Karkaar and Bari regions, who have been pleasantly helpful and forthcoming during field research in central and northeast Somalia.

${ }^{2}$ Hansen, SJ. Piracy in the greater Gulf of Aden: Myths, misconceptions and remedies. Oslo: Norsk institutt for by- og regionsforskning, 2009; Percy, S \& Shortland A. "The pirates of Somalia: Coastguards of anarchy". London: Centre for Economic Development and Institutions, Brunel University 42/9. 
2009; Murphy, M. Somalia: The new Barbary? Piracy and Islam in the Horn of Africa. London: Hurst, 2011; Weldemichael, AT. "Maritime corporate terrorism and its consequences in the western Indian Ocean: Illegal fishing, waste dumping and piracy in twenty-first-century Somalia". Journal of the Indian Ocean Region 8/2. 2012. 110-126.

${ }^{3}$ Murphy op. cit., pp. 5-7.

${ }^{4}$ Author's dataset. "Somali Piracy Data", on pirate incidents off the Horn of Africa, 1991-2014. Unpublished. Dataset available upon request.

${ }^{5}$ Author's dataset op. cit.

${ }^{6}$ Author's dataset op. cit.

${ }^{7}$ Murphy op. cit., pp. 14-15; National Geospatial-Intelligence Agency (hereafter NGIA), Anti-shipping Activity Messages (hereafter ASAM), Reference no. 2002-12; NGIA, ASAM, No. 2001-64; NGIA, ASAM, No. 2000-338.

${ }^{8}$ NGIA, ASAM, No. 2001-64.

${ }^{9}$ NGIA, ASAM, No. 2002-12; NGIA, ASAM, No. 2001-118.

${ }^{10}$ Google Earth. "Somalia, Horn of Africa". Version 7.0.3.8542. Data SIO, NOAA, US Navy, NGA, GEBCO, Image Landsat. 〈http://www.earth.google.com> Accessed on 15 March 2015; Author's dataset op. cit.

${ }^{11}$ Author's dataset op. cit.

${ }^{12}$ Coffen-Smout, S. "Pirates, warlords and rogue fishing vessels in Somalia's unruly seas". 1998. <http://www.chebucto.ns.ca/ ar120/somalia.html > Accessed on 15 March 2015.

${ }^{13}$ Weldemichael op. cit., p. 110.

${ }^{14}$ Ibid., p. 115.

${ }^{15}$ Murphy op. cit.

${ }^{16}$ Author's dataset op. cit.

${ }^{17}$ Ibid.

${ }^{18}$ NGIA, ASAM, No. 1991-4; 1991-16; 1991-24; 1991-40; 1993-57; 1994-12; 1994-42; 1994-53; 1995-7; 1995-8; 1995-71; 1995-86; Author's dataset op. cit.

${ }^{19}$ Author's dataset op. cit.

${ }^{20}$ Marchal, R. "Somali piracy: The local contexts of an international obsession". Humanity: An International Journal of Human Rights, Humanitarianism, and Development 2/1. 2001. 38.

${ }^{21}$ Murphy op. cit.; Weldemichael op. cit.

${ }^{22}$ Weldemichael op. cit., p. 118.

${ }^{23}$ Ibid. 
${ }^{24}$ Coffen-Smout op. cit.

${ }^{25}$ Murphy op. cit., p. 13.

${ }^{26}$ Dua, J. "A sea of trade and a sea of fish - piracy and protection in the Western Indian Ocean". Journal of Eastern African Studies 7/2. 2013. 365; Dua, J \& Menkhaus, K. "The context of contemporary piracy". Journal of International Criminal Justice 10/4. 2012. 759.

${ }^{27}$ Global Environment Facility. "Somalia: National Marine Ecosystem Diagnostic

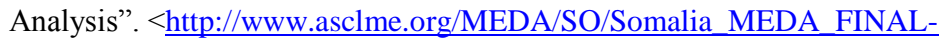
Electronic.pdf> Accessed on 15 March 2015.

${ }^{28}$ Ibid.; Yassin, M. "Somali fisheries development and management". Master thesis. Oregon State University, 1981. 3.

${ }^{29}$ Marchal op. cit., p. 38

${ }^{30}$ Murphy op. cit., p. 22.

31 Ibid.

32 Ibid.

${ }^{33}$ Ibid., p. 23.

${ }^{34}$ Bahadur, J. The pirates of Somalia: Inside their hidden world. New York: Pantheon Books, 2011. 18.

35 Ibid., p. 64; Marchal op. cit., p. 38; Murphy op. cit., pp. 23-25.

${ }^{36}$ Bahadur op. cit., p. 66.

${ }^{37}$ Ibid., p. 19.

${ }^{38}$ Bahadur op. cit., p. 67.

${ }^{39}$ Murphy op. cit., pp. 23-24.

${ }^{40}$ Ibid., p. 67.

${ }^{41}$ Gatehouse, J. "This cabbie hunts pirates". 12 January 2009.

<http://www.macleans.ca/news/world/this-cabbie-hunts-pirates/> Accessed on 15 March 2015.

${ }^{42}$ Author's dataset op. cit.

${ }^{43}$ Murphy op. cit., p. 21.

${ }^{44}$ Author's interview with (anonymised) member of Eyl District Council.

Conducted with aid of researcher 'Muse', 25 March 2014.

${ }^{45}$ Author's interview with Garowe security analyst 'Rashid', 31 August 2014.

${ }^{46}$ Author's observation, Garacad, 22 October 2013.

${ }^{47}$ Bahadur op. cit., p. 66; Marchal op. cit., pp. 37-38.

${ }^{48}$ Hansen op. cit., p. 25.

49 Ibid.

${ }^{50}$ Author's dataset op. cit. 
${ }^{51}$ Hansen op. cit., p. 25.

${ }^{52}$ Bahadur op. cit., p. 35.

${ }^{53}$ Hansen op. cit., pp. 23-24.

${ }^{54}$ NGIA, ASAM, No. 2003-146.

55 Author's dataset op. cit; NGIA, ASAM, No. 2004-43; NGIA, ASAM, No. 2004172.

${ }^{56}$ Author's dataset op. cit.

${ }^{57}$ PDRC. "Peacemaking at the crossroads: Consolidation of the 1993 Mudug Peace Agreement". Dialogue for Peace - Somali Programme. September 2006. 8.

${ }^{58}$ PDRC op. cit. 8.

${ }^{59}$ CRD. "Promoting security and stabilisation among the communities of southcentral Somalia”. July 2006. 23.

<http://www.interpeace.org/publications/somali-region/54-dialogue-notguns-english/file> Accessed on 15 March 2015; Danish Immigration Service. "Human rights and security in central and southern Somalia". March 2004. 19. <http://www.refworld.org/pdfid/405b2d804.pdf> Accessed on 15 March 2015.

${ }^{60}$ CRD. "Community-based peace processes in South-Central Somalia”. July 2008. 85 .

<http://www.interpeace.org/wpcontent/uploads/2008/07/2008_SomSC_Interpeace_CRD_Community_Base d_Peace_Processes_EN.pdf $>$ Accessed on 24 October 2015.

${ }^{61}$ Ibid.

${ }^{62}$ CRD. "In pursuit of peace - challenges and opportunities in the central regions". July 2012. 20. <http://www.interpeace.org/publications/somali-region/324pillars-of-peace-in-pursuit-of-peace-english/file> Accessed on 15 March 2015.

${ }^{63}$ CRD, "Community-based peace..." op. cit., p. 85.

${ }^{64}$ Google Earth. "Central Somalia”. Version 7.0.3.8542. Data SIO, NOAA, US Navy, NGA, GEBCO, Image Landsat. 〈http://www.earth.google.com> Accessed on 15 March 2015.

${ }^{65}$ BBC. “'Dozens dead' in Somalia clashes”. 6 December 2004. <http://news.bbc.co.uk/2/hi/africa/4073063.stm > Accessed on 15 March 2015.

${ }^{66}$ BBC. "“Dozens dead' in Somalia clashes". 6 December 2004. <http://news.bbc.co.uk/2/hi/africa/4073063.stm> Accessed on 15 March 2015; CRD, “Community-based peace...”op. cit., p. 86. 
67 Ibid.

68 Ibid.

${ }^{69}$ BBC. "“Dozens dead' in Somalia clashes". 6 December 2004. <http://news.bbc.co.uk/2/hi/africa/4073063.stm> Accessed on 15 March 2015.

${ }^{70}$ BBC. "Rival Somali clans fight for land". 12 January 2006. <http://news.bbc.co.uk/2/hi/africa/4606882.stm> Accessed on 15 March 2015.

${ }^{71}$ Salad, O, Haugsjå, H \& Jamalle, MES. “Assessment report 2011 - For Galmudug, Himan and Heb, Galgaduud and Hiiraan regions, Somalia”. 2011. 40. <https://docs.unocha.org/sites/dms/Somalia/Yme\%20NorSom\%20GSA\%20 ASSESSMENT\%20REPORT\%202011\%20Final\%20Report.pdf > Accessed on 15 March 2015.

72 Food Security Analysis Unit. "2005 Post Gu Analysis”. Technical Series IV/7. 13 September 2005. 40.

${ }^{73}$ Salad et al. op. cit., p. 16.

${ }^{74}$ Ibid.

${ }^{75}$ Hansen op. cit., p. 25; Murphy op. cit., p. 58.

${ }^{76}$ PDRC op. cit., p. 15; AllAfrica. "13 reported killed in inter-clan fighting in Mudug”. 13 April 2005. < http://allafrica.com/stories/200504130703.html> Accessed on 15 March 2015.

77 Author's interview with Mayor of Eyl, Muse Osman Yusef. Conducted with the aid of researcher 'Muse', 26 March 2014.

${ }^{78}$ Percy \& Shortland op. cit.; Shortland, A. "“Robin Hook': The developmental effects of Somali piracy". DIW Berlin Discussion Papers 1155. 2011; Dua \& Menkhaus op. cit.; Dua op. cit.

${ }^{79}$ Marchal op. cit.; Murphy, MN. "The troubled waters of Africa: Piracy in the African littoral". The Journal of the Middle East and Africa 2/1. 2011. 6583; Anning, A \& Smith, MLR. "The accidental pirate: Reassessing the legitimacy of counterpiracy operations”. 2012.

${ }^{80}$ Hansen op. cit.

${ }^{81}$ Fielding, PJ \& Mann, BQ. "The Somalia inshore lobster resource”. IUCN Eastern Africa Programme. June 1999. <https://portals.iucn.org/library/sites/library/files/documents/1999-088.pdf> Accessed on 15 March 2015; Weldemichael op. cit.

${ }^{82}$ A 'black swan' event signifies the onset of sudden, unprecedented and long-term changes to an environment. 
${ }^{83}$ Rose, J \& Muse, AH. "The day the sea died: Evaluation of the ACT response to the tsunami disaster in Somalia”. Norwegian Church Aid. 2007. 11. <https://www.kirkensnodhjelp.no/contentassets/3147be4c564d45c19290e7a 9f12db86f/report-on-somalia-tsunami-reponse-pdf.pdf> Accessed on 15 March 2015.

${ }^{84}$ Annunziato, A \& Best, C. The tsunami event: Analyses and models. Ispra, Italy: Joint Research Center, European Commission, January 2005. 8; Fritz, HM \& and Borrero, JC. "Somalia field survey after the December 2004 Indian Ocean tsunami”. Earthquake Spectra 22/3. June 2006. 219-233.

${ }^{85}$ Annunziato \& Best op. cit., p. 8.

${ }^{86}$ Fritz \& Borrero op. cit., pp. 219-221.

${ }^{87}$ Fritz \& Borrero op. cit.; UN Development Programme. "Hafun to Gara'ad: Northeast Somali Coastline - Mission: $28^{\text {th }}$ January to $8^{\text {th }}$ February 2005 ". 30 March 2005.

<http://www.who.int/hac/crises/international/asia_tsunami/som/somalia_rep ort_8feb.pdf> Accessed on 15 March 2015.

${ }^{88}$ Google Earth. "Western and Eastern Indian Ocean”. Version 7.0.3.8542. Data SIO, NOAA, US Navy, NGA, GEBCO, Image Landsat.

<http://www.earth.google.com> Accessed on 15 March 2015; NOAA Center for Tsunami research. "Maximum wave height $(\mathrm{cm})-2004.12 .26$ Indonesian tsunami". < http://nctr.pmel.noaa.gov/indo20041226/max.pdf $>$ Accessed on 15 March 2015; Titov, V, Rabinovich, AB, Mofjeld, HO, Thomson, RE \& González, FI. "The global reach of the 26 December 2004 Sumatra tsunami”. Science 309. 23 September 2005. 2045-2048; UN OCHA. "Africa, South Asia, Southeast Asia countries affected by earthquake \& tsunami”. 3 January 2005. <http://www.esri.com/news/arcnews/spring05articles/spring05gifs/p2p2lg.jpg> Accessed on 15 March 2015.

${ }^{89}$ Ryu, A. "Report from Somalia: Islamists oppose pirates on Somali Coast". Hiiraan Online. 22 December 2008. <http://www.hiiraan.com/news2/2008/dec/report_from_somalia_islamists_o ppose_pirates_on_somali_coast.aspx > Accessed on 15 March 2015.

${ }^{90}$ Burale, DM. "FAO post tsunami assessment mission to central and south coast of Somalia". Food and Agriculture Organization, Somalia Office. 2005. 1-23.

${ }^{91}$ Author's interview with Bandarbeyla fisherman, Musse Ali Jama. Conducted with aid of researcher 'Muse', 21 April 2014. 
92 Tello, G. "Fisheries tsunami emergency programme - Somalia: End of mission report”. Food and Agriculture Organization, Somalia Office. October 2005. 10.

93 AllAfrica. "Somalia: WFP ships additional supplies to tsunami stricken Somalia". 11 January 2005. <http://allafrica.com/stories/200501110259.html> Accessed on 15 March 2015.

${ }^{94}$ Mojon, J-M. "In the heart of Somali piratedom". 10 September 2010. <http://www.sundaytimes.lk/100905/International/int_06.html > Accessed on 15 March 2015.

${ }^{95}$ UNICEF. Somalia Monthly Review. January 2005. 1.

${ }^{96}$ UN Development Programme op. cit., p. 31.

${ }^{97}$ Tello op. cit., pp. 12, 25-26.

${ }^{98}$ Ibid., pp. 14, 33.

99 Author's interview, 25 March 2014 op. cit.

${ }^{100}$ Author's interview, 26 March 2014 op. cit.

${ }^{101}$ Author's interview, 25 March 2014 op. cit.

${ }^{102}$ Author's focal group conversation with Aris fishermen. Conducted with aid of researcher 'Muse', 23 April 2014.

103 Author's interview with (anonymised) Eyl inhabitant, Jihan. Conducted with aid of researcher 'Muse', 22 March 2014; Author's interview, 25 March 2014 op. cit.

${ }^{104}$ Author's interview, 26 March 2014 op. cit.; Author's interview, 22 March 2014 op. cit.

105 Author's interview, 25 March 2014 op. cit.

106 Author's interview, 21 April 2014 op. cit.

107 Author's interview, 26 March 2014 op. cit.

108 Author's interview, 21 April 2014 op. cit.

${ }^{109}$ UN Development Programme op. cit., pp. 23-24.

${ }^{110}$ Author's interview with Eyl fisherman, Abdirizak Abshir Guled. Conducted with aid of researcher 'Muse', 22 March 2014b.

${ }^{111}$ UN Development Programme op. cit.

${ }^{112}$ Weldemichael op. cit.

113 Ibid., p. 10.

114 Author's interview, 26 March 2014 op. cit.

115 Ibid., p. 27.

${ }^{116}$ Burale op. cit., p. 19.

${ }^{117}$ UN Development Programme op. cit., p. 27. 
${ }^{118}$ Hansen op. cit.

119 Author's interview with (anonymised) pirate from Haber Gedir Suleiman clan. Conducted with aid of researcher 'Muse', 15 May 2014.

${ }^{120}$ Ibid.

${ }^{121}$ Author's interview, 22 March 2014b op. cit.; Author's interview, 21 April 2014 op. cit.

${ }^{122}$ Author's interview, 15 May 2014 op. cit.

${ }^{123}$ Google Earth. "Somalia, Horn of Africa" op. cit.

${ }^{124}$ Ibid.

${ }^{125}$ Murphy, Somalia: The new Barbary? op. cit., p. 80.

${ }^{126}$ Author's interview, 15 May 2014 op. cit.

${ }^{127}$ Hansen op. cit.

${ }^{128}$ International Maritime Organization. "Reports on Acts of Piracy and Armed Robbery Against Ships”. MSC.4/Circ.67. April 2005.

${ }^{129}$ Murphy, Somalia: The new Barbary? op. cit., p. 32.

${ }^{130}$ International Maritime Organization. "Reports on Acts of Piracy and Armed Robbery Against Ships”. MSC.4/Circ.68. May 2005.

${ }^{131}$ Murphy, Somalia: The new Barbary? op. cit., p. 32.

${ }^{132}$ BBC. "Pirates hijack tsunami aid ship". 30 June 2005. <http://news.bbc.co.uk/2/hi/africa/4636695.stm > Accessed on 15 March 2015.

133 Author's dataset op. cit.

${ }^{134}$ NGIA, ASAM, No. 2005-216.

135 NGIA, ASAM, No. 2005-291.

136 Ibid.

${ }^{137}$ UNSC. Report of the Secretary-General on the situation in Somalia. S/2006/122. 2006. 6

${ }^{138}$ NGIA, ASAM, No. 2006-91.

${ }^{139}$ Atuna. "Somali pirates demand $\$ 400,000$ for release tuna vessel”. 10 April 2006. < http://www.atuna.com/NewsArchive/ViewArticle.asp?ID=3450 $>$ Accessed on 15 March 2015.

${ }^{140}$ Google Earth "Central and South Somalia". Version 7.0.3.8542. Image Landsat, Data SIO, NOAA, US Navy, NGA, GEBCO.

<http://www.google.com/earth/> Accessed on 15 March 2015; Author's dataset op. cit. 
${ }^{141}$ Gale, I. "US Navy and Somalis 'tracking cargo ship"”. GulfNews. 5 November 2006. <http://gulfnews.com/news/region/somalia/us-navy-and-somalistracking-cargo-ship-1.264475> Accessed on 15 March 2015.

142 Barnes, C \& Hassan, H. "The rise and fall of Mogadishu's Islamic courts". Journal of Eastern African Studies 2/1. 2007. 151-160; Barnes, C \& Hassan, H. "The rise and fall of Mogadishu's Islamic courts". Africa Programme. April 2007. <https://www.chathamhouse.org/sites/files/chathamhouse/public/Research/A frica/bpsomalia0407.pdf $>$ Accessed on 15 March 2015; Menkhaus op. cit.; Hansen op. cit.

${ }^{143}$ Hansen op. cit. 27.

${ }^{144}$ Author's dataset op. cit.

${ }^{145}$ CRD, "Promoting security ..." op. cit., p. 88.

${ }^{146}$ Ibid., p. 89.

${ }^{147}$ Salad, O. "Visits to Nairobi and Mudug region". Somali Initiative for Dialogue and Democracy: Review of Developments 2006-2007. 2007.

<http://www.sidd.org.uk/kulemba/SIDD\%20Review\%202006\%20Master\%2 0\%28w\%20photos\%29.pdf > Accessed on 15 March 2015.

148 BBC. "Somalia's Islamists deny advance". 16 August 2006. <http://news.bbc.co.uk/2/hi/africa/4797573.stm > Accessed on 15 March 2015; BBC. "Trawler safe after pirate ordeal". 6 August 2006. <http://news.bbc.co.uk/2/hi/africa/5249684.stm> Accessed on 15 March 2015.

${ }^{149}$ BBC, "Somalia's Islamists deny advance" op. cit.

${ }^{150}$ Barnes \& Hassan, Africa Programme op. cit., p. 4.

${ }^{151}$ Salad op. cit., p. 6.

152 Ibid.; Author's interview, 21 April 2014 op. cit.

${ }^{153}$ Salad op. cit., p. 6.

${ }^{154}$ Burale op. cit., p. 19.

${ }^{155}$ Salad op. cit., p. 6.

${ }^{156}$ Author's dataset op. cit.

${ }^{157}$ Author's dataset op. cit.

158 Author's interview with 'Hala' (anonymised), 26 September 2014.

${ }^{159}$ Author's interview with 'John' (anonymised), 26 September 2014.

${ }^{160}$ Ibid.

${ }^{161}$ Author's dataset op. cit.

${ }^{162}$ Hansen op. cit., p. 32. 
163 Jablonski, RS \& Steven Oliver. "The political economy of plunder: Economic opportunity and modern piracy”. Journal of Conflict Resolution 57/4. 2012. 10.

${ }^{164}$ Marchal, R. "A tentative assessment of the Somali Harakat Al-Shabaab". Journal of Eastern African Studies 3/3. 2009. 393.

${ }^{165}$ Menkhaus, K. "The crisis in Somalia: Tragedy in five acts". African Affairs 106/204. 2007. 386.

${ }^{166}$ UNOCHA. Consolidated Appeal for Somalia 2008. December 2007. 1; Menkhaus op. cit., pp. 357-358.

${ }^{167}$ Hansen op. cit., p. 32.

${ }^{168}$ PDRC. Newsletter 13. September 2007. 1.

${ }^{169}$ PDRC. "Puntland note: Mapping the foundations of peace - Challenges to security and rule of law, democratisation process and devolution of power to local authorities". Pillars of Peace Programme. November 2010. 13.

${ }^{170}$ PDRC Newsletter op. cit., p. 1.

${ }^{171}$ Hansen op. cit., p. 32. 